\title{
2. DYSPROPORCJE W ROZWOJU SYSTEMU PRZYRODNICZEGO ŁODZI
}

\subsection{Wstęp}

Rozwój miast, niegdyś silnie uzależniony od warunków środowiska przyrodniczego (m.in. warunków gruntowo-wodnych i rzeźby terenu), obecnie nawiązuje również do obszarów przyrodniczych położonych w ich granicach, jednak $\mathrm{w}$ nieco innym kontekście. Współcześnie elementy środowiska przyrodniczego w mieście, określane coraz częściej jako infrastruktura ekologiczna ${ }^{1}$, pełnią przede wszystkim funkcje środowiskotwórcze, użytkowe i estetyczne. Do głównych funkcji środowiskotwórczych zalicza się napowietrzanie miasta, regulacje klimatu i stosunków wodnych, zmniejszanie zanieczyszczań oraz poprawę stanu przyrody żywej, natomiast funkcje użytkowe wiążą się z funkcjami rekreacyjnymi i technicznymi, a także w coraz mniejszym stopniu z funkcją produkcyjną. Funkcje estetyczne zaś, określane również jako percepcyjne, wynikają z zaspokajania potrzeby bezpośredniego kontaktu z przyrodą (Czerwieniec, Lewińska 2000, Przewoźniak 2002, za: Sołtys 2010). Obecność obszarów przyrodniczych o dużych walorach (urozmaicona rzeźba, wody, kompleksy leśne i inne tereny zieleni) z jednej strony sprzyja więc koncentracji funkcji rekreacyjnych, z drugiej zaś tereny otwarte preferowane są dla rozwoju budownictwa mieszkaniowego - zwłaszcza o charakterze rezydencjalnym. W związku z tym nierównomierne rozmieszczenie elementów systemu przyrodniczego miasta ${ }^{2}$, które jest pochodną kształtowania się struktury funkcjonalno-przestrzennej w całym okresie jego rozwoju, może wpływać na dysproporcje w zagospodarowaniu przestrzeni miejskiej, obserwowane

1 Termin infrastruktura ekologiczna wprowadzili badacze holenderscy Wijnands i Vereijken (1992) w odniesieniu do obszarów wiejskich, jednak jest on coraz częściej stosowany dla określenia elementów systemu przyrodniczego miasta (por. Szulczewska, Kaliszuk 2005).

2 Pojęcie system przyrodniczy miasta używane jest zgodnie z definicją B. Szulczewskiej i J. Kaftana (1996) dla określenia wyodrębnionej części miasta, która pełni nadrzędne funkcje przyrodnicze (klimatyczną, hydrologiczną, biologiczną) oraz podporządkowane im funkcje pozaprzyrodnicze. 
głównie w lokalizacji terenów rekreacyjnych i zabudowy mieszkaniowej jednorodzinnej, a także terenów przemysłowych związanych $\mathrm{z}$ wydobyciem surowców.

Współczesny krajobraz Łodzi, wyrażający się w zagospodarowaniu przestrzeni miejskiej, jest efektem rozwoju osadnictwa, które na początkowym etapie w znacznym stopniu determinowane było warunkami środowiska przyrodniczego, a dopiero w późniejszych okresach rozwoju stanowiło wypadkową czynników naturalnych i procesów społecznych oraz gospodarczych. Środowisko naturalne (niezmienione bądź zmienione w niewielkim stopniu przez człowieka) występowało na obszarze dzisiejszej Łodzi do początku minionego tysiąclecia i ulegało stopniowo przemianom (zwłaszcza dotyczącym pokrywy roślinnej i świata zwierzęcego) w średniowieczu wraz z rozwojem najstarszych osad, do których S. M. Zajączkowski (1973) zalicza Kały, Łagiewniki, Radogoszcz i Modrzew (Koter 1974). W największym stopniu środowisko przyrodnicze uległo przemianom w okresie kształtowania Łodzi przemysłowej (XIX i XX w.) kiedy to, w związku z rozbudową przemysłu włókienniczego i możliwościami technologicznymi, przeobrażone zostały stosunki wodne, ukształtowanie powierzchni oraz warunki klimatyczne (Koter 1974). W połowie lat 70. wieku XX zwrócono uwagę na negatywne skutki tej nadmiernej ingerencji w środowisko przyrodnicze miasta, które wyrażały się $\mathrm{m}$. in. niedoborem wód wgłębnych (czwartorzędowych), zanieczyszczeniem atmosfery i degradacją życia biologicznego (Krzemiński 1974).

Zaliczając do systemu przyrodniczego Łodzi tereny wyodrębnione prawnie i funkcjonalnie, tj. lasy, łąki i inną zieleń naturalną, tereny rolnicze, ogródki działkowe, parki i cmentarze oraz wody, zwraca uwagę ich nierównomierne rozmieszczenie $\mathrm{w}$ przestrzeni miasta. Intensyfikacja zabudowy, szczególnie w centralnej części terenu objętego współcześnie granicami Łodzi, doprowadziła do znacznego uszczuplenia obszarów przyrodniczych, które obecnie cechuje peryferyjne położenie (ryc. 2.1). W centrum miasta znajdują się przede wszystkim tereny miejskiej zieleni publicznej oraz niewielkie enklawy zieleni naturalnej, na peryferiach zaś dominują tereny rolnicze (związane $\mathrm{z}$ dawnymi wsiami włączonymi w granice Łodzi w roku 1988) oraz łąki i lasy. W celu ukazania dysproporcji $\mathrm{w}$ rozmieszczeniu elementów systemu przyrodniczego $\mathrm{w}$ mieście, w dalszej części pracy zaprezentowano warunki środowiska przyrodniczego determinujące ich występowanie. 


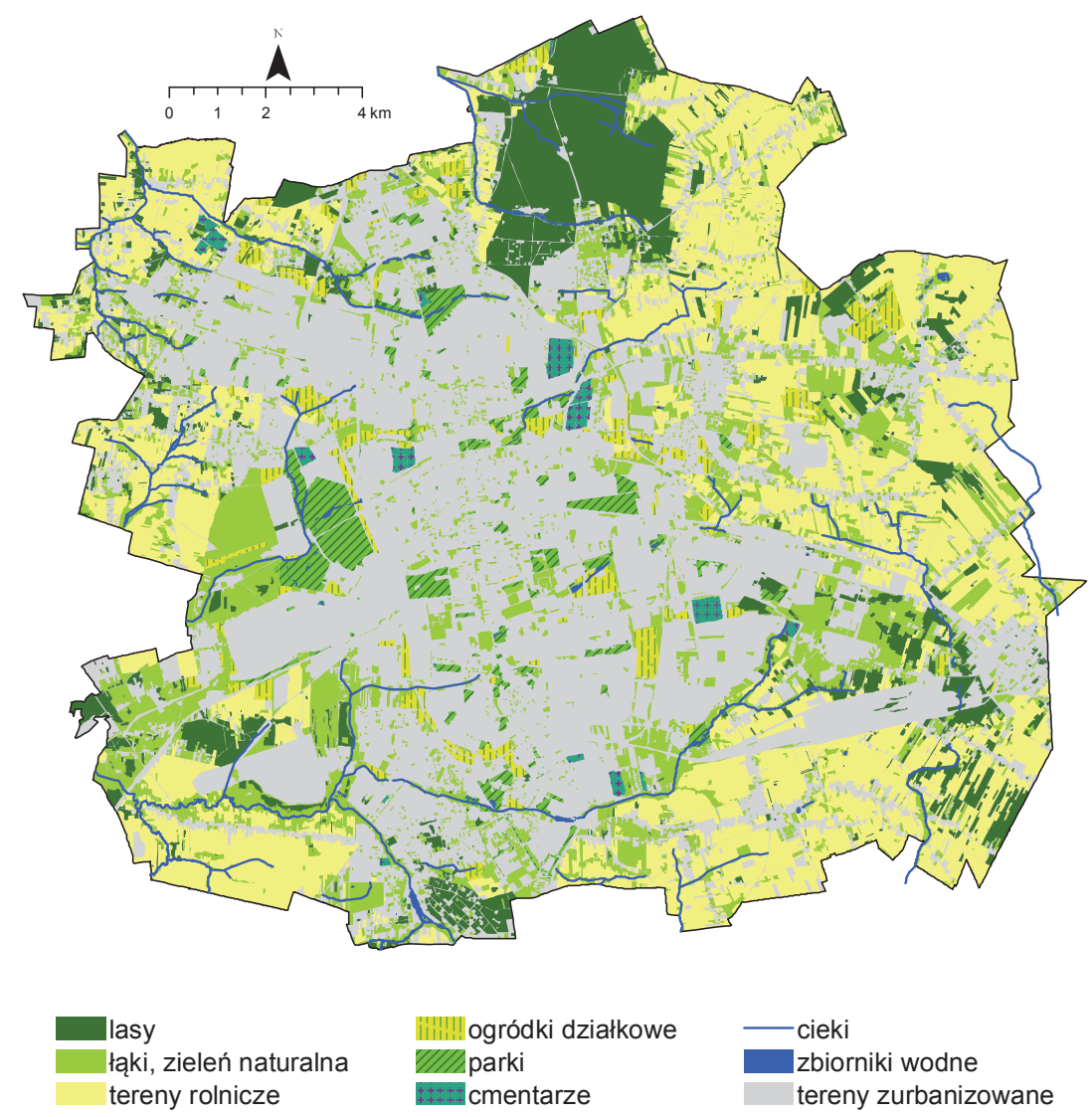

Ryc. 2.1. Wybrane elementy systemu przyrodniczego Łodzi Źródło: opracowanie własne na podstawie Studium... 2010

\subsection{Wybrane elementy środowiska przyrodniczego}

\subsubsection{Położenie Łodzi na tle podziałów fizycznogeograficznych}

Łódź położona jest w pobliżu geograficznego środka Polski, w granicach współrzędnych geograficznych: $51^{\circ} 51^{\prime} 40^{\prime \prime} \mathrm{N}$ na północ, $51^{\circ} 41^{\prime} 11^{\prime \prime} \mathrm{N}$ na południe, $19^{\circ} 20^{\prime} 41^{\prime \prime}$ E na zachód i $19^{\circ} 38^{\prime} 30^{\prime \prime}$ E na wschód. Rozciągłość południkowa Łodzi wynosi 19,5 km natomiast rozciągłość równoleżnikowa 17,49 km. Paradoksalnie, konsekwencją centralnej lokalizacji Łodzi jest jej położenie w strefie pośredniej wpływów genetycznie różnych czynników środowiska geograficznego, tworzących niekiedy wrażenie peryferyczności Łodzi, ale także potęgujących jej indywidualność w szeregu aspektów przyrodniczych, społecznych i gospodarczych.

Położenie Łodzi można rozpatrywać w kontekście różnych podziałów, których podstawę konstrukcji stanowią zwykle odmienne aspekty środo- 
wiska przyrodniczego. W zakresie geomorfologii powierzchni i jej genezy, miasto położone jest w centralnej części regionu łódzkiego (Turkowska 2006), którego naturalną granicę od zachodu stanowi dolina środkowej Warty a od wschodu doliny Pilicy i Rawki. Północna i południowa granica regionu wynikają z genezy rzeźby regionu, stanowiącego centralną część warciańskiej strefy staroglacjalnej. Stąd obszar regionu łódzkiego wyznacza od południa maksymalny zasięg lądolodu stadiału Warty zlodowacenia Odry (Lindner, Marks 2012), a od północy maksymalny zasięg zlodowacenia Wisły.

Natomiast w świetle podziału fizycznogeograficznego Polski (Kondracki 1998), zbudowanego na podstawie zasadniczych elementów środowiska geograficznego (budowa geologiczna, rzeźba terenu, klimat, stosunki wodne, gleba, organizmy żywe, człowiek), Łódź położona jest w obszarze podprowincji Niziny Środkowopolskie (318), w makroregionach: Wzniesienia Południowomazowieckie (318.8) i Nizina Południowowielkopolska (318.1) oraz w mezoregionach: Wzniesienia Łódzkie (318.82) - północna i wschodnia część miasta i Wysoczyzna Łaska (318.19) - zachodnia część miasta.

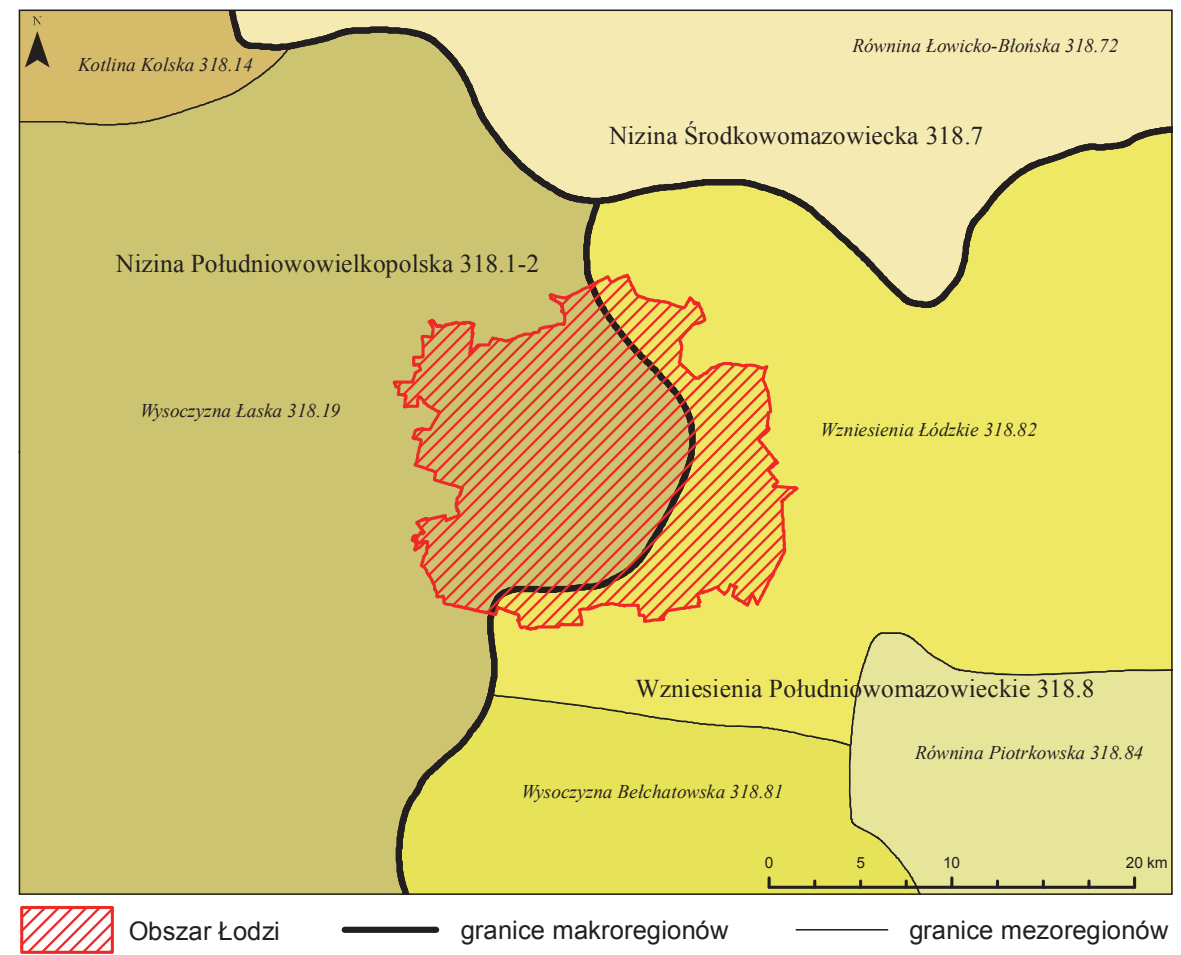

Ryc. 2.2. Łódź na tle podziału fizycznogeograficznego Polski wg J. Kondrackiego Źródło: opracowanie własne na podstawie Kondracki (1998) 


\subsubsection{Budowa geologiczna}

Łódź położona jest na styku dwóch jednostek geologiczno-strukturalnych Polski (Alexandrowicz 1999), w przeważającej części w obrębie synklinorium szczecińsko-łódzko-miechowskiego, w jednostce niższego rzędu wchodzącej w skład synklinorium, tj. niecce łódzkiej. Północnowschodnia część miasta leży w obrębie wału kujawskiego (antyklinorium środkowopolskie), tj. zachodniego skrzydła antykliny Justynowa (Nowacki, Trzmiel 1987). Osady górnojurajskie, budujące wał kujawski, wyłaniają się spod utworów dolnej i górnej kredy, wypełniających nieckę łódzką. Granica pomiędzy jednostkami przebiega przed osiedla Wzniesień Łódzkich, Doliny Łódki, Mileszek, Olechów-Janów, nr 33, Andrzejów i wschodnią część Wiskitna. Zaleganie utworów charakteryzuje się bardzo dużą stromością, co na mapie zaznacza się w postaci wąskich pasów o przebiegu NW-SE. Wśród skał górnojurajskich dominują wapienie kimerydu (stwierdzone w okolicach Nowosolnej i Andrzejowa) oraz margle i margle mułowcowe (rejon Mileszek). Utwory wieku kredowego reprezentowane są przez piaskowce i piaski dolnokredowe (rejon Wiskitna) oraz górnokredowe wapienie, opoki i margle turonu, koniaku, santonu i kampanu (m.in. rejon Chojen i Bronisina) (Nowacki, Trzmiel 1987). W okolicach Nowosolnej rozpoznano wychodnie margli i wapieni z górnej jury, natomiast nieco na zachód oprócz margli starsze podłoże budują gezy, piaskowce z glaukonitem, żwirem i fosforytami oraz krzemienie górnokredowe (Klatkowa, Piwocki 1981, Piwocki 1980). W pasie od Chojen przez Dąbrowę do Widzewa Wschód, pod pokrywą czwartorzędową zachowały się kredowe ostańce erozyjno-denudacyjne, tworzące w rzeźbie podłoża wyraźną krawędź morfologiczną (Nowacki, Trzmiel 1987).

Obszar Łodzi pokrywa nieciągła warstwa osadów neogenu, której miąższość waha się od kilkunastu centymetrów do około $80 \mathrm{~m} \mathrm{w}$ rejonach spiętrzeń glacitektonicznych (Nowacki, Trzmiel 1987). Stąd wniosek, iż powierzchnia mezozoiczna w wielu wypadkach jest także powierzchnią podczwartorzędową (Piwocki 1980, Klatkowa, Piwocki 1981). Sytuacja ta cechuje niemal cały obszar Polski Środkowej. Neogen stanowią osady miocenu i pliocenu. Miocen rozpoznany został w postaci piasków, iłów i mułków z węglem brunatnym, powszechnych w północno-wschodniej części Łodzi (rejon Stoków) oraz iłów i piasków kwarcowych w zachodniej części miasta (np. rejon Żabieńca). Pliocen rozpoznany jest w postaci występujących płatowo sekwencji iłów, mułków i piasków (rejon Chojen), odpowiadających sekwencjom iłów poznańskich (Nowacki, Trzmiel 1987).

Morfologia podłoża przedczwartorzędowego ma znaczący wpływ zarówno na warunki sedymentacji osadów w czwartorzędzie, jak i na charakter współczesnej rzeźby powierzchni. Pośrednio determinuje więc 
obecny charakter użytkowania powierzchni, także w sferze miasta. Ma to swoje konsekwencje w rozmieszczeniu funkcji mieszkaniowej, produkcyjnej (obejmującej gospodarkę surowców naturalnych) i rekreacyjnej.

Powierzchnię Łodzi budują w główniej mierze skały osadowe wieku czwartorzędowego, których miąższość waha się od kilkudziesięciu do około 150 metrów w części północno-wschodniej. Dominują piaszczysto-żwirowe utwory wodnolodowcowe, gliny morenowe oraz osady mułowo-ilaste, związane z sedymentacją fluwialną i glacifluwialną (Nowacki 1993; Nowacki, Trzmiel 1984).

Najważniejszy wpływ na ukształtowanie współczesnej powierzchni Łodzi i obszarów podłódzkich miały zlodowacenia środkowopolskie, w tym przede wszystkim ostatnie w środkowej Polsce nasunięcie lądolodu warty. Utwory warciańskie tworzą w obrębie Łodzi złożoną mozaikę. Gliny zwałowe budują południową i centralną część miasta. Obniżenia pomiędzy płatami glin wypełniają piaszczyste osady wodnolodowcowe. W obrębie tych zasadniczych typów osadów płatowo występują mułki oraz iły spiętrzone glacitektonicznie (znane z rejonu Stoków i Parku Krajobrazowego Wzniesień Łódzkich). W południowej części Łodzi zalegają osady piaszczyste, żwiry i miejscami mułki tworzące pagórki kemowe. Na utwory warciańskie nałożone są osady vistulianu i holocenu, występujące w dolinach rzecznych. Stanowią je piaski, żwiry i mułki fluwialne budujące tarasy nadzalewowe oraz piaski rzeczne i namuły den dolinnych i zagłębień bezopływowych wieku holoceńskiego (Różycki, Kulczyński 1962, Nowacki, Trzmiel, 1987, Ziomek, Iwańcz, Laskowski 2002). Przy zachodniej granicy miasta (gmina Aleksandrów Łódzki) w dorzeczu Neru położone jest torfowisko Rąbień objęte ochroną rezerwatową, którego osady (torfy i gytie) datuje się na późny vistulian i holocen (Balwierz 2005, Forysiak 2012).

Budowa geologiczna ma zasadniczy wpływ na lokalizację gospodarki surowcowej w mieście. W średniowieczu eksploatacji podlegała bagienna ruda darniowa wykorzystywana w kuźniach w Rudzie Pabianickiej i przy młynie Kulom. Od końca XVIII wieku eksploatowano również piaski dla potrzeby prymitywnego hutnictwa szkła m.in. w Kałach, Żabieńcu, Rogach, Chojnach i w okolicy Wiskitna (Koter 1974). Natomiast w okresie międzywojennym istniało w Łodzi już ponad 30 cegielni zlokalizowanych głównie na jej ówczesnych przedmieściach (Wesołowski 2002).

Współcześnie, największe tereny górnicze położone są w północno-wschodniej części Łodzi i związane są z zaleganiem miąższych utworów piaszczysto-żwirowych budujących pagórki morenowe. Do nieczynnych już żwirowni należą odkrywki kopalni „Stoki”, „Iglasta”, „Listopadowa” i „Pomorska”, znajdujące się na północ od ulicy Pomorskiej a także tereny w zachodniej części Nowosolnej. Do częstych praktyk należało tworzenie w odkrywkach poeksploatacyjnych wysypisk śmieci (np. rejon Nowosol- 
nej, Rudzka Góra). Eksploatacji surowców zarówno na skalę przemysłową, jak i drobną - gospodarczą podlegały także południowe rejony miasta, w obszarach występowania pagórków kemowych. Do takich miejsc należą obszary Chojen (rejony ul. Kolumny), Wiskitna i dalszych osiedli, pozostających już poza granicami miasta (Starowa Góra, Konstantyna, Wola Zaradzyńska). Tendencja ta przejawiała się wraz z rozwojem osadnictwa i „rozrastaniem się” Łodzi w kierunku południowym. Niestety większość odkrywek nie podlegała rekultywacji i stanowi dziś nieużytek pogórniczy.

Z budowy geologicznej Łodzi wynikają warunki budowlane. Najkorzystniejsze warunki budowlane związane z podłożem gliniastym, o właściwościach twardoplastycznych, mogą występować w centralnej części miasta (dzielnice: Śródmieście, Górna), oraz w północno-wschodniej i wschodniej części miasta - na osiedlu Stoki (ryc. 2.3), co wynika z zalegania dużych miąższości utworów piaszczystych średnio zagęszczonych bądź zagęszczonych, w których poziom wody gruntowej występuje poniżej poziomu przemarzania gruntu, tj. $1 \mathrm{~m}$ (PN-81 B-03020).

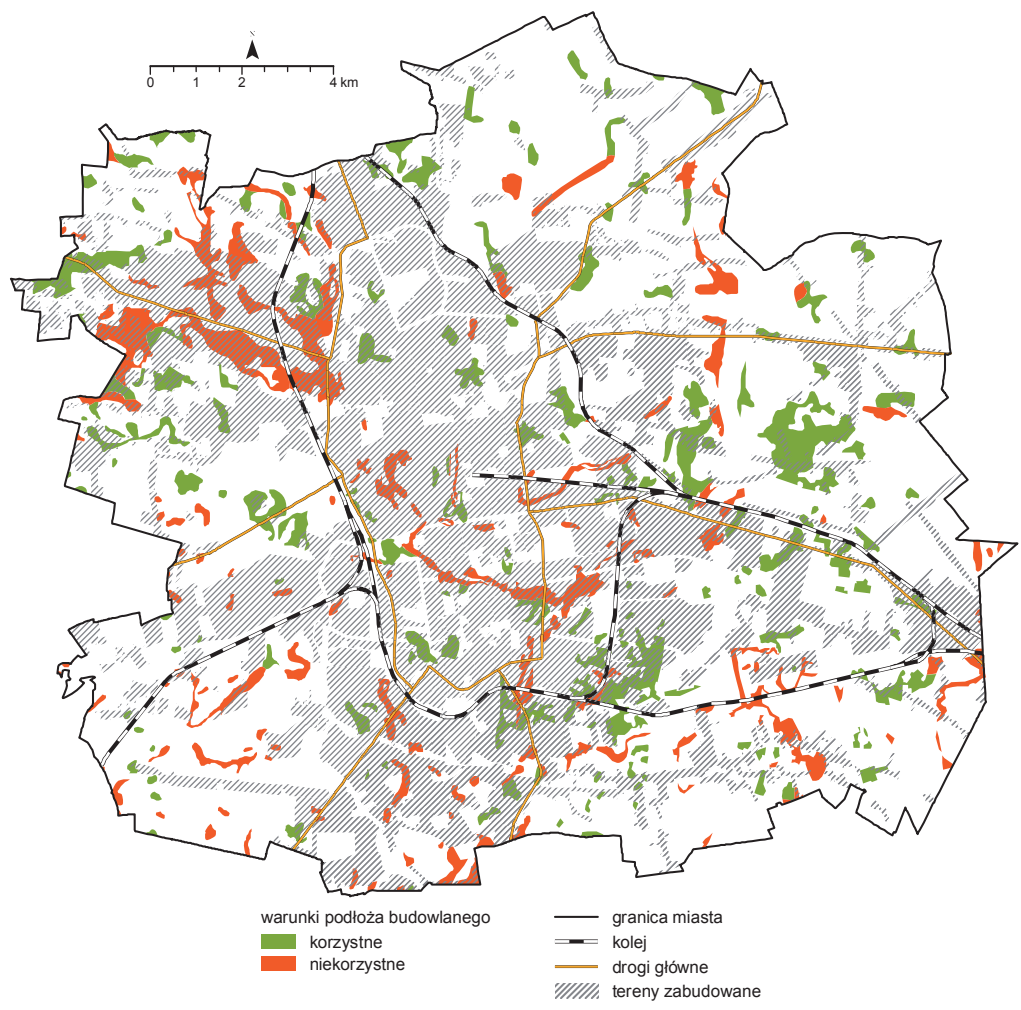

Ryc. 2.3. Warunki podłoża budowlanego $\mathrm{w}$ Łodzi

Źródło: opracowanie własne na podstawie serwisu WMS Centralnej Bazy Danych Geologicznych 
Mimo pełnej regulacji rzek w mieście i ich skanalizowaniu, dzięki czemu nie stwarzają one większego zagrożenia wylewami, niekorzystne warunki budowlane są typowe dla dużych dolin rzecznych, w których zalegają osady nienośne, tj. namuły, torfy, piaski luźne oraz utrudniające budownictwo płytko występujące wody gruntowe. Powierzchniowa budowa geologiczna Łodzi stanowi zasadniczo mozaikę osadów o własnościach korzystnych bądź niekorzystnych z punktu widzenia budownictwa, dlatego konieczne jest każdorazowe wykonanie badań geotechnicznych dla posadowienia nowych obiektów budowlanych. Jednak ze względu na rozwój technik budownictwa warunki budowlane nie stanowią obecnie szczególnej przeszkody w realizacji zamierzonych w mieście inwestycji.

\subsubsection{Rzeźba powierzchni}

Rzeźba powierzchni Łodzi w głównej mierze jest efektem zlodowaceń środkowopolskich, w tym przede wszystkim działalności lądolodu warty. Obszar ten już w latach pięćdziesiątych XX w. został wyróżniony jako „kraina podłódzka” (Dylik 1948b), ze względu na swoją peryferyczność w stosunku do największych dolin rzecznych (Wisły i Warty), wododziałowe położenie i indywidualność rzeźby powierzchni, odrębne w stosunku do sąsiednich terenów.

Łódź położona jest w obszarze wysoczyznowym, którego orograficzną oś stanowi wyżynny półwysep zwany garbem łódzkim, jego podstawę wyznacza rzędna 200,0 m n.p.m. (Dylikowa 1973). Rzeki biorące początek w kulminacjach wysoczyzny mają wąskie i płytkie doliny, nie wpływające na jej rozbicie. Spływają promieniście, w kierunku wschodnim i zachodnim. Główne elementy rzeźby uformowane w czasie zlodowacenia warty to formy morenowe w typie moreny dennej, budujące trzon orograficznej osi wysoczyzny oraz pagórki moren czołowych, występujące w północno-wschodniej części miasta. Obniżenia pomiędzy płatami morenowymi wypełniają piaszczysto-żwirowe formy sandrowe (największy sandr znajduje się w rejonie Widzewa i osiedli Bałuty Zachodnie, Teofilów, Złotno). W osi południowej części miasta zaznacza się ciąg pagórków kemowych (pagórki Rudzkie i Chojeńskie - ryc. 2.4), powstałych w efekcie arealnego zaniku lądolodu warty, jako wypełnienia otwartych szczelin pomiędzy bryłami martwego lodu (Dylik 1948a, Klatkowa 1972). Pomiędzy pagórkami kemowymi oraz na równinach sandrowych (Bałuty, Teofilów) licznie występują małe zagłębienia bezodpływowe o genezie wytopiskowej (Goździk, Wieczorkowska 2002). 


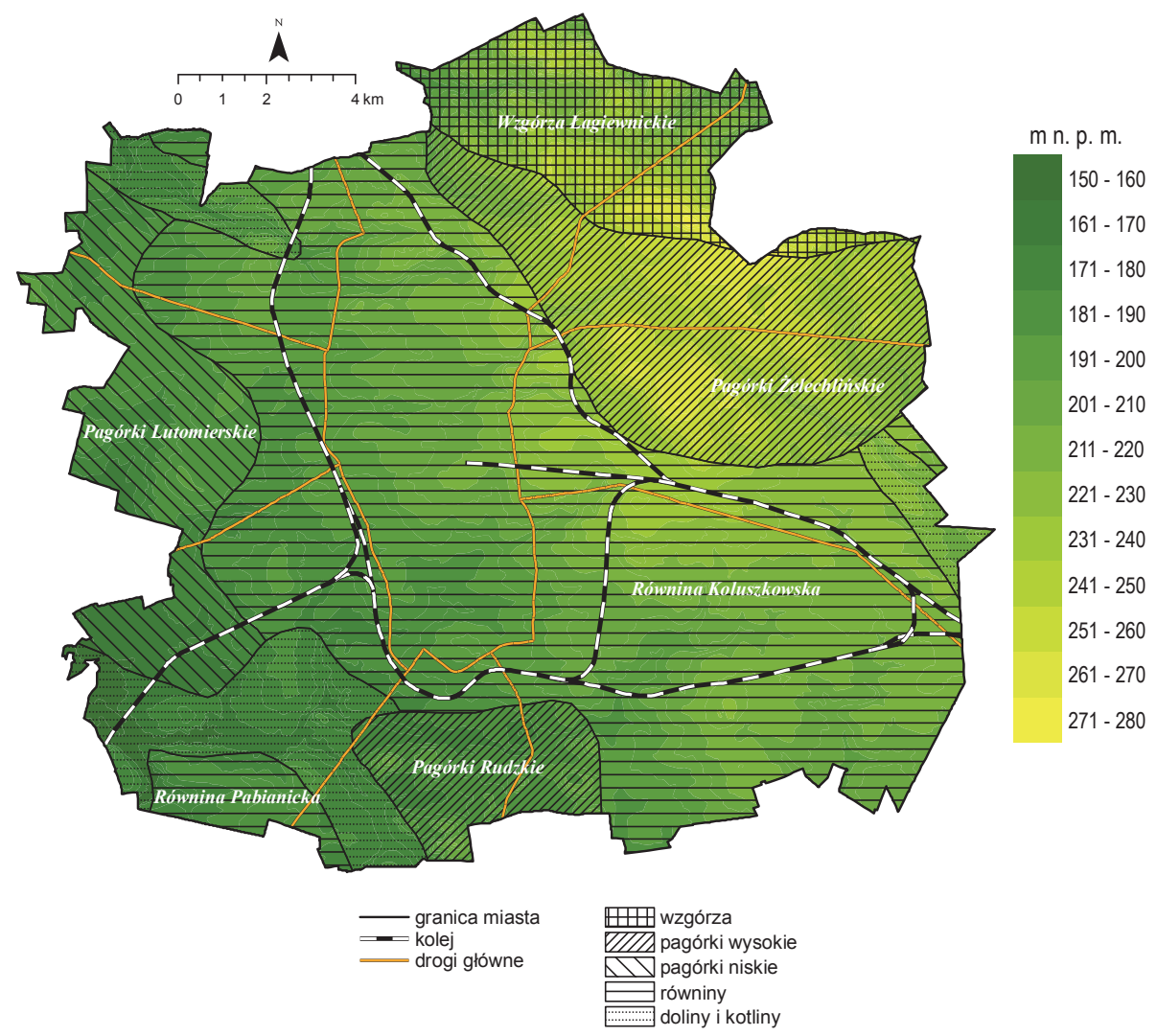

Ryc. 4. Jednostki morfograficzne i ukształtowanie powierzchni Łodzi Źródło: opracowanie własne na podstawie Dylik 1948a

Na rzeźbę glacjalną obszaru Łodzi nakładą się efekty morfogenezy $\mathrm{w}$ warunkach klimatu peryglacjalnego panującego w czasie zlodowacenia Wisły i umiarkowanego w różnych odmianach (okres interglacjału eemskiego i holocen). Formy powstałe w warunkach klimatu zimnego to doliny denudacyjne, stanowiące ważny element rzeźby Wzniesień Łódzkich oraz wyższe tarasy rzeczne dolin, przede wszystkim Neru, Łódki i Sokołówki. Z okresem holocenu związana jest współczesna sieć rzeczna.

Antropogeniczne przekształcenia rzeźby obejmują przede wszystkim środkowy pas miasta, dzielnice Bałuty, Śródmieście i Górną. Przekształcenia wynikają z wyrównywania naturalnych deniwelacji terenu pod inwestycje drogowe i budowlane, w tym zasypywania naturalnych den dolin. Przykłady stanowią niwelacja naturalnego garbu terenowego pod Plac Wolności (dawny Rynek Nowego Miasta) i przy tym zasypywanie doliny Łódki (rejon ul. Nowomiejskiej), plantowanie Rynku Starego Miasta i zasypywanie mokradeł w rejonie ul Sienkiewicza (dawnej ul. Dzikiej) 
(Diehl 1997), lub podwyższenie Rudzkiej Góry w efekcie jej przekształceń z 208 m n. p. m. (według Topographische Karte, ark. Ruda Pabianitzka z 1944 r.) do 230,2 m n. p. m. obecnie.

Na obszarze Łodzi wysokości bezwzględne zasadniczo maleją z północnego wschodu na południowy zachód, to samo dzieje się z intensywnością rzeźby. Jest to ściśle związane z grubością pokrywy osadów czwartorzędowych. Obszarom o najbardziej żywej rzeźbie odpowiadają strefy największych miąższości osadów lodowcowych. Największe wartości spadków terenu związane są z północno-wschodnimi rejonami miasta, z formami tworzącymi Wzniesienia Łódzkie (pagórkami morenowymi, ostańcami denudacyjnymi) oraz z wzniesieniami w osiedlach Stoki, Sikawa, Nowosolna i południowo-zachodnimi rejonami Widzewa. Wzdłuż linii Zgierz-Brzeziny przebiega najwyraźniejszy odcinek tych wzniesień, stanowiący tak zwaną strefę krawędziową Wyżyny Łódzkiej.

Zgodnie z interpretacją Klatkowej (1965) stopnie strefy krawędziowej Wyżyny Łódzkiej powstały w środowisku glacjalnym, jako efekt spychania i spiętrzania osadów transgredującego lądolodu warty na obszar wysoko wyniesionego podłoża mezozoicznego. Przez kulminacje Wzniesień Łódzkich przebiega linia głównego działu wodnego pomiędzy dorzeczami Wisły i Odry. Najwyższy punkt o rzędnej 282,9 m n.p.m. leży za granicą administracyjną miasta, na granicy wsi Dąbrowa i Nowosolna. Na obszarze miasta najwyżej położone wzniesienie o wysokości 276,6 m n. p. m. występuje na Stokach (ul. Giewont). Kulminacje wysoczyzny związane są także z południową częścią miasta, tj. strefą występowania południkowego ciągu pagórków kemowych (rejon osiedli Ruda, Józefów, Chojny, Nowe Górki, Wiskitno), a także z pewnymi odcinkami dolin niektórych rzek (Sokołówki, Neru, Miazgi).

Rzeźba terenu łagodnieje w kierunku północno-wschodnim, przechodząc od intensywnej w rejonie północno-wschodnim, w strefie krawędzi Wyżyny Łódzkiej, poprzez łagodnie zondulowaną powierzchnię Śródmieścia, w rozległą równinę na zachodzie (Zdrowie, Retkinia, Rokicie). Najniższy punkt na obszarze Łodzi o rzędnej $170,0 \mathrm{~m} \mathrm{n}$. p. m. położony jest w dolinie Neru, w miejscu jej przecięcia przez granice miasta.

Łódź cechuje znaczna energia rzeźby wyrażona w różnicy wysokości względnej. Różnica pomiędzy najwyższym i najniższym punktem na przestrzeni $14 \mathrm{~km}$ wynosi około $107 \mathrm{~m}$. Największa energia rzeźby charakteryzuje północno-wschodnią część miasta (obszar Wzgórz Łagiewnickich) oraz jego południowe rejony - Pagórki Rudzkie i Chojeńskie, gdzie różnice wysokości bezwzględnych $\mathrm{w}$ polach podstawowych o powierzchni $0,25 \mathrm{~km}^{2}$ sięgają ponad $35 \mathrm{~m}$. Centralna, zurbanizowana część Łodzi ma znacznie mniejszą energię rzeźby - wskaźnik wysokości względnych na tym terenie nie przekracza kilku metrów (ryc. 2.5). 


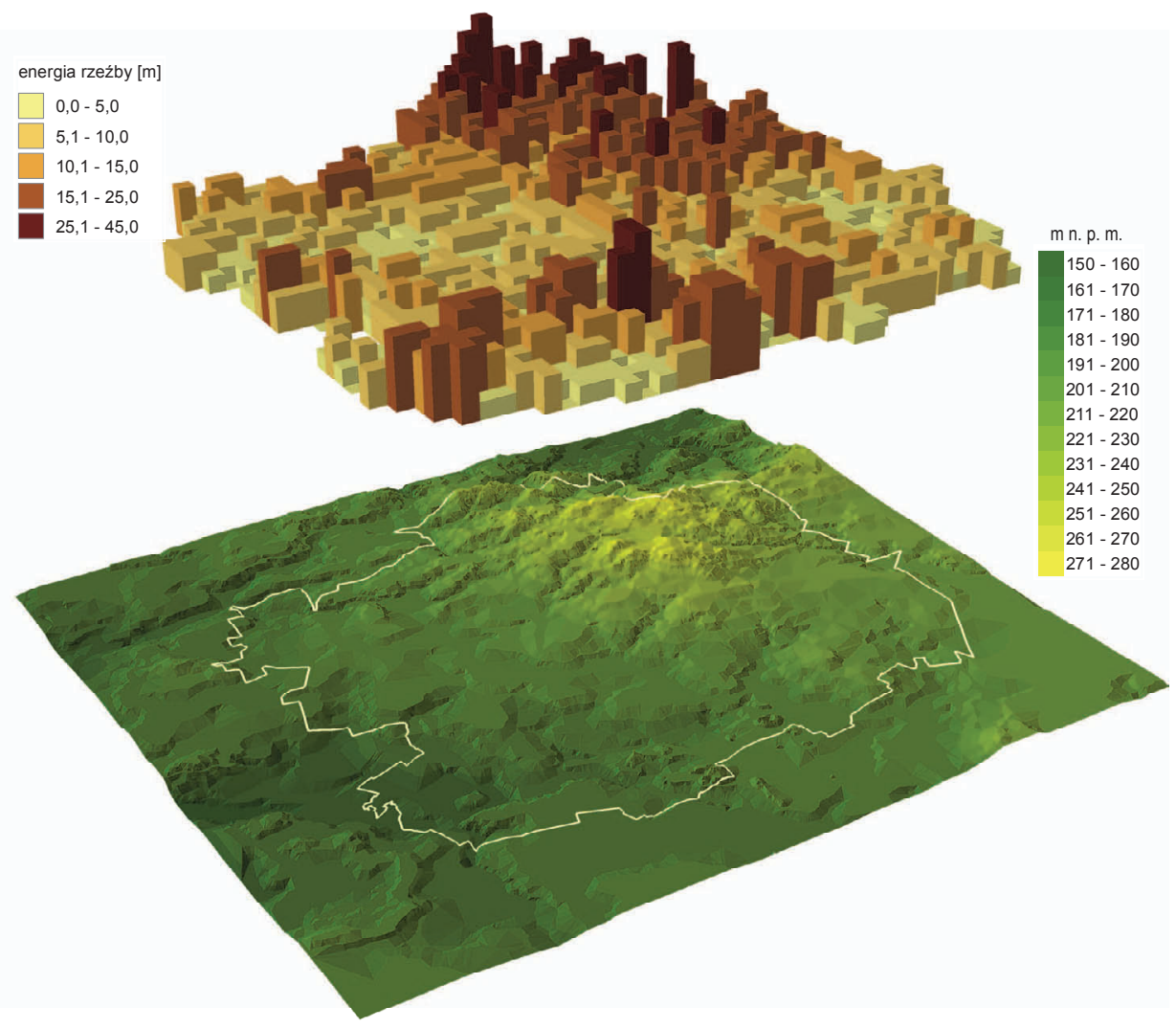

Ryc. 2.5. Energia rzeźby i ukształtowanie powierzchni Łodzi Źródło: opracowanie własne

\subsubsection{Sieć rzeczna}

Łódź położona jest na głównym dziale wodnym Polski (I rzędu), rozdzielającym dorzecza Odry i Wisły. Północna i północno-wschodnia część miasta znajduje się w dorzeczu Bzury (zlewnia Wisły) natomiast pozostała jego część leży w dorzeczu Neru (zlewnia Odry). Węzeł hydrograficzny, w którym zbiegają się linie wododziałów położony jest w rejonie Nowosolnej i Moskulik. Obecnie na terenie miasta płynie 18 rzek o łącznej długości ok. $110 \mathrm{~km}$ (tab. 2.1, ryc. 2.6). Współcześnie są to niewielkie cieki w całości uregulowane, które w centrum miasta płyną w podziemnych kanałach. Do II połowy wieku XIX Łódź była bogata i zasobna w wody powierzchniowe, co potwierdza opis miasta z 1825 r. Według Stanisława Staszica Łódź „znajduje się z całą swoją rozległa okolica pod obszernem i wyniosłem wzgórzem, z którego niezliczone tryszczq źródła..." 


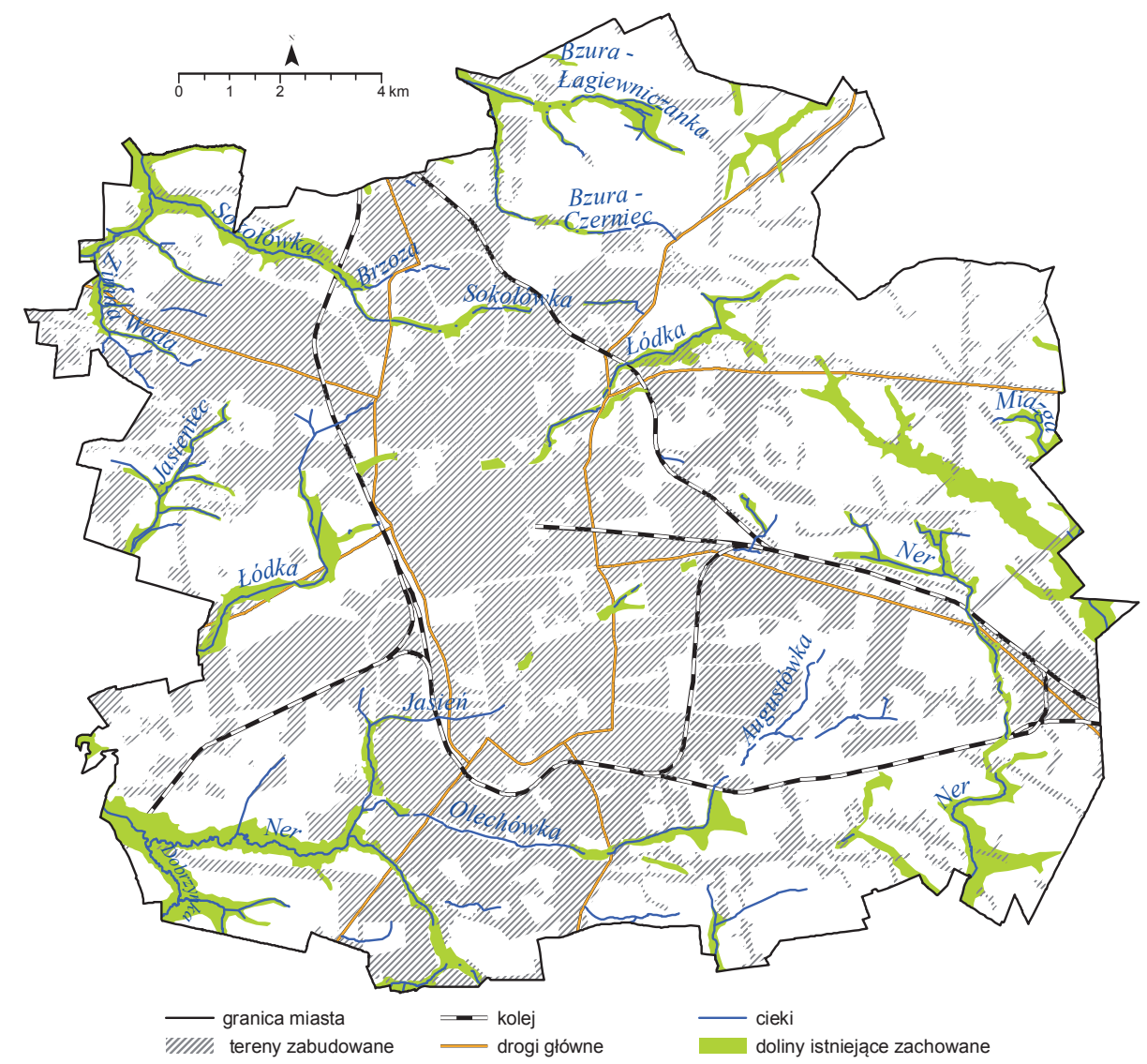

Ryc. 2.6. Sieć rzeczna Łodzi

Źródło: opracowanie własne na podstawie Studium... 2010

Tabela 2.1

Zestawienie rzek Łodzi

\begin{tabular}{|l|l|}
\hline \multicolumn{1}{|c|}{ Dorzecze Bzury (zlewnia Wisły) } & \multicolumn{1}{c|}{ Dorzecze Neru (zlewnia Odry) } \\
\hline Bzura (dopływ Wisły) & Ner (dopływ Warty) \\
\hline Łagiewniczanka (dopływ Bzury) & Gadka (dopływ Neru) \\
\hline Sokołówka (dopływ Bzury) & Dobrzynka (dopływ Neru) \\
\hline Brzoza (dopływ Sokołówki) & Jasieniec (dopływ Neru) \\
\hline Wrząca (dopływ Sokołówki) & Jasień (dopływ Neru) \\
\hline Aniołówka (dopływ Sokołówki) & Łódka (dopływ Neru) \\
\hline Zimna Woda (dopływ Aniołówki) & Karolewka (dopływ Jasienia) \\
\hline Miazga (dopływ Wolbórki) & Olechówka (dopływ Jasienia) \\
\hline & Augustówka (dopływ Olechówki) \\
\hline & Bałutka (dopływ Łódki) \\
\hline
\end{tabular}

Źródło: Z biegiem łódzkich rzek, 2010, Urząd Miasta Łodzi, Łódź. 
Przebieg wododziałów na terenach intensywnie zurbanizowanych jest niepewny, ze względu na trudności z określeniem rzeczywistego kierunku spływu wód. Rzeki i strumienie spływają z Garbu Łódzkiego promieniście, zasilając główne systemy rzeczne Polski środkowej (Koter, Liszewski, Suliborski 2000).

Poza rzekami, na terenie miasta funkcjonuje szereg bezimiennych cieków, całkowicie przekształconych antropogenicznie (płynące w rowach i odpływach kanalizacji deszczowej) stanowiących pozostałość po bogatej sieci rzecznej Łodzi.

Położenie strefy źródłowej łódzkich rzek - Wzniesień Łódzkich, w bliskiej odległości od aglomeracji wpływa niekorzystnie na tutejsze stosunki wodne. Na skutek obniżenia zwierciadła wód gruntowych, część cieków wyschła lub funkcjonuje okresowo (Łódka, Jasień). Istotny negatywny wpływ ma także zanieczyszczenie ściekami (Nowacki, Trzmiel 1987). Przepuszczalność gruntów jest bardzo zróżnicowana ze względu na ich silne antropogeniczne przekształcenie (Maksymiuk, Jokiel 1993).

\subsubsection{Wody podziemne}

Łódź położona jest w strefie występowania obfitych zasobów wód podziemnych w obszarze niecki łódzkiej. W latach 1820-1935 stanowiły one jedyne źródło zaopatrzenia ludności zarówno w celach gospodarczych jak i przemysłowych (Diehl 1997). Ich eksploatacja była czynnikiem decydującym o powstaniu i rozwoju przemysłowym Łodzi.

Rozpoznane poziomy wodonośne a zarazem użytkowe, związane są z utworami dolnej i górnej kredy, neogenu i czwartorzędu. Wody podziemne neogenu, ze względu na utrudnione warunki hydrogeologiczne, mają jedynie lokalne znaczenie użytkowe. Najgłębszym, eksploatowanym poziomem wodonośnym są wody dolnokredowe. Zarówno wody dolno-, jak i górnokredowe są typu infiltracyjnego i występują pod dużym ciśnieniem hydrostatycznym. Charakteryzują się dogodnymi warunkami hydrogeologicznymi. Są to wody typu dwuwęglanowo-wapniowego. Poziom górnokredowy użytkowany jest w dzielnicach zachodniej części miasta i w Śródmieściu. Efektem ich intensywnej eksploatacji jest duży lej depresyjny, będący powodem wyłączenia znacznej liczby studni z użytkowania. Jego zasięg nie objął jedyne południowej i południowo-zachodniej części miasta, który to obszar uznaje się za perspektywiczny dla ujęcia wód GPU górnej kredy (Nowicki 2007).

Występowanie wód podziemnych w utworach czwartorzędowych związane jest z piaszczysto-żwirowymi utworami wodnolodowcowymi. Wraz z poziomami wód w utworach kredowych stanowią one podstawę zaopatrzenia Łodzi w wodę pitną. W obszarze miasta stwierdzono wystę- 
powanie czterech zasadniczych poziomów - płytki (wód gruntowych), nadmorenowy, śródmorenowy i podmorenowy. Poziomy śród- i podmorenowy stanowią główną warstwę użytkową szczególnie we wschodniej części miasta. Wody te odznaczają się korzystnymi warunkami hydrogeologicznymi, stąd występujące poniżej wody, związane z utworami górnej jury, w obrębie wału kujawskiego, nie podlegają eksploatacji.

Łódź zaopatrywana jest w wodę pitną z trzech systemów wodociągowych:

- Sulejów-Łódź, bazującego na wodach powierzchniowych zbiornika Sulejowskiego w Bronisławowie i na ujęciu wód podziemnych górnej kredy Adamów-Bronisławów,

- Tomaszów-Łódź, bazującego na ujęciu wód powierzchniowych Pilicy w Tomaszowie Mazowieckim oraz ujęciu wód podziemnych górnej jury w Rokicinach oraz

- Łódź, opartego wyłącznie na ujęciach wód podziemnych.

W Łodzi funkcjonuje pięć zasadniczych ujęć wodociągowych: Dąbrowa, Mirecki, Żabieniec, Teofilów i Sikawa-Stoki oraz osiem mniejszych, opartych na lokalnych ujęciach wód podziemnych (Mileszki, Podklasztorze, Łukaszewska, Imielnik, Nowosolna, Okulska, Henrykowska, Żółwiowa). Następuje ciągła rozbudowa ujęć wód podziemnych wynikająca z planu zastępowania ujęć wód powierzchniowych. Południowa część miasta jest obecnie zaopatrywana wyłącznie z ujęć wód podziemnych.

W rejonie Łodzi występują trzy Główne Zbiorniki Wód Podziemnych: GZWP nr 401 - Niecka Łódzka, GZWP nr 403 - Zbiornik międzymorenowy Brzeziny-Lipce Reymontowskie oraz GZWP nr 404 - Zbiornik Koluszki-Tomaszów górnej jury. Jest to obszar najbardziej perspektywiczny dla Łodzi, w świetle eksploatacji wód podziemnych ze względu na dużą zasobność i korzystne parametry hydrogeologiczne (Nowicki 2007). Łódzką wodę cechuje bardzo wysoka jakość, jest jedną z najlepszych i najtańszych wód dostarczanych do miast w Polsce: 37 studni położonych jest w mieście i na jego obrzeżach, a w 22 z nich woda jest tak dobrej jakości, że nie wymaga uzdatniania (studnie o głębokości od 100 do 901 metrów czerpiące wodę z poziomu czwartorzędowego górnej i dolnej kredy).

\subsubsection{Gleby}

Zróżnicowanie typologiczne gleb zależy od skał macierzystych, stanowiących podłoże dla ich uformowania. W Łodzi są to przede wszystkim utwory polodowcowe - piaski i żwiry fluwioglacjalne oraz gliny zwałowe, w mniejszym stopniu utwory deluwialne (stoki wzniesień), aluwialne i organiczne (doliny rzek). Dominują tu gleby wytworzone na piaskach, występujące płatowo, na całym obszarze Łodzi. Są to przede wszystkim gleby brunatne (południowo i południowo-zachodnia część miasta) 
i bielicoziemne w tym rdzawe, dominujące w dzielnicach Bałuty (osiedla Łagiewniki, Radogoszcz), Widzew (Andrzejów, Mileszki) i Górna (Ruda, Rokicie). Gleby płowe i opadowo-glejowe występujące na glinach stanowią około $20 \%$ w ogólnej powierzchni użytków rolnych. Wytworzone na pyłach gliniastych gleby płowe pokrywają obszary Nowosolnej, Stoków, Mileszek, Doliny Łódki. Czarne ziemie mają podobny udział w powierzchni użytków rolnych (południowe i zachodnie osiedla). Nieznaczny procent stanowią mady rzeczne i gleby organogeniczne - torfowe, murszowe, wytworzone na piaskach luźnych i gleby mułowe. Związane są z obniżeniami terenu i dnami dolin rzecznych, głównie w dzielnicach Górna i Polesie. Duży odsetek stanowią gleby antropogeniczne o niewykształconym profilu, obejmujące centralne osiedla miasta, występujące na terenach zrekultywowanych po kopalniach piasku i żwiru oraz gleby parków i terenów zielonych w mieście (ryc. 2.7).

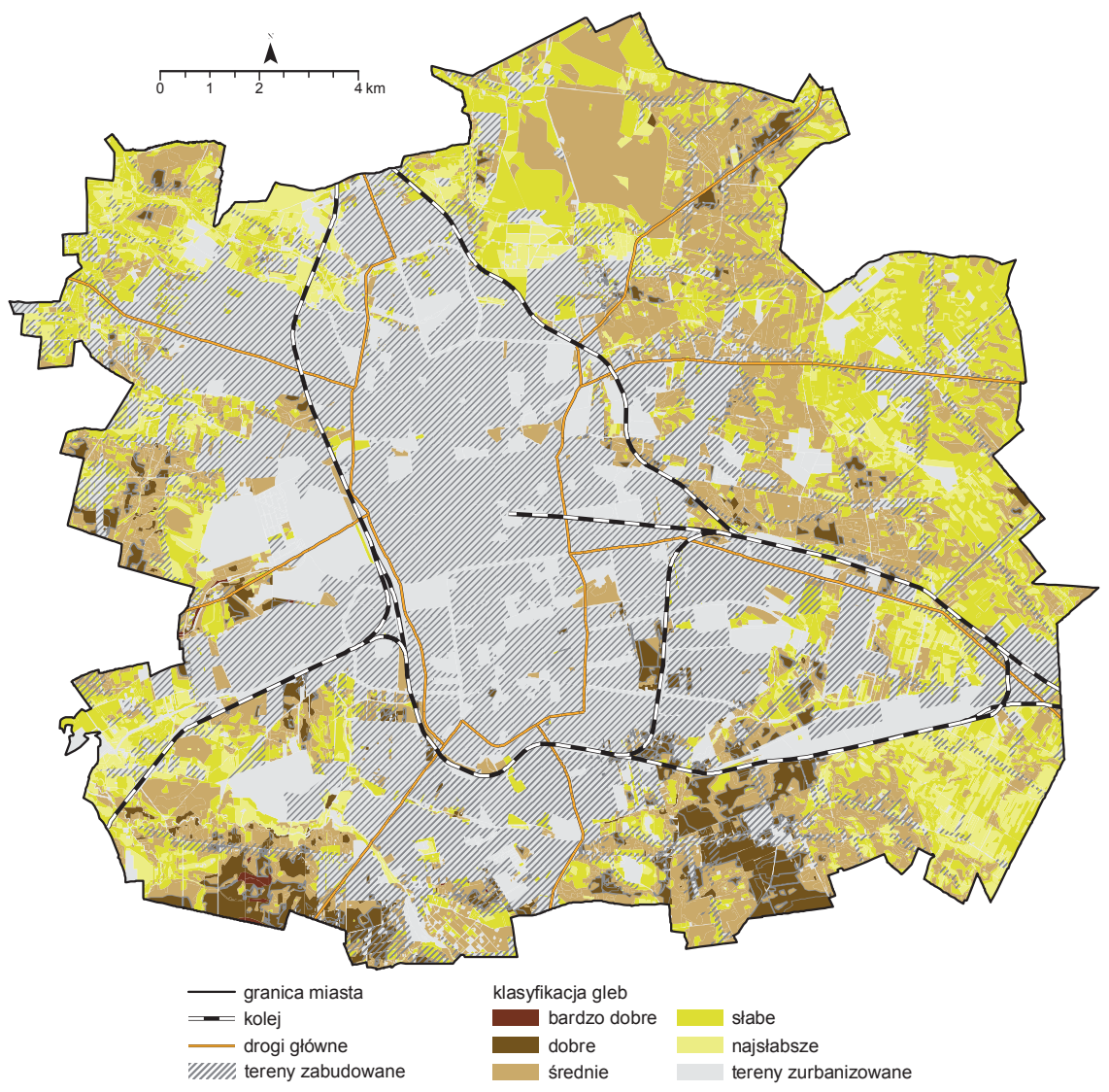

Ryc. 2.7. Bonitacja gleb w Łodzi

Źródło: opracowanie własne na podstawie danych MODGiK 
Pomimo niekorzystnych warunków naturalnych, do których należały żywa rzeźba terenu, ustronność położenia z dala od większych rzek oraz zwarta pokrywa leśna, początki osadnictwa Łodzi przypadające na okres od początku XV do początku XIX w., związane są z rolnictwem. Osadnictwo o charakterze rolniczym skupiało się wówczas w zachodniej części obecnego obszaru miasta, w dolinach większych rzek (Neru, Olechówki, Łódki i Sokołówki) oraz na obszarach zalegania przede wszystkim gleb bielicowych, rdzawych i brunatnych (Ziomek, Iwańcz, Laskowski 2002).

\subsubsection{Klimat}

W świetle naturalnych warunków klimatycznych Łódź leży w obszarze przejściowym, pomiędzy strefą oddziaływania wpływów oceanicznych od zachodu i kontynentalnych od wschodu, charakterystycznych dla Niżu Polskiego. Zróżnicowanie przestrzenne wybranych komponentów klimatu na obszarze Łodzi wynika z oddziaływania czynników lokalnych. Na klimat Łodzi wpływ ma bliskie położenie Wzniesień Łódzkich, stanowiących orograficzną przeszkodę dla mas powietrza płynących ze wschodu. Klimat Łodzi wykazuje więcej cech oceanicznych niż np. Warszawy (Diehl 1997). Cechą obszaru Łodzi jest niewielkie zróżnicowanie temperatury powietrza oraz wartości rocznych amplitud, mniejsze od tych notowanych dla Poznania, co również świadczy o znacznym wpływie klimatu oceanicznego. Zakłócenia $\mathrm{w}$ naturalnym rytmie termicznym sprzyjające podwyższaniu temperatury $\mathrm{w}$ mieście, powodują zanieczyszczenie powietrza, sztuczne ciepło oraz inercyjne oddziaływanie zabudowy miejskiej na wymianę ciepła. Czynniki kształtujące termiczny reżim Łodzi w świetle zjawiska miejskiej wyspy ciepła badał Fortuniak (2003). Zarówno struktura urbanistyczna Łodzi, jak i warunki naturalne podkreślają jej lokalną indywidualność klimatyczną. Miasto stanowi samoistny czynnik klimatotwórczy.

Różnice temperatury pomiędzy obszarami zwartej zabudowy a peryferiami miasta sięgają $2^{\circ} \mathrm{C}$. Silniejsza konwekcja nad miastem, wywołana wyższą temperaturą i zanieczyszczeniem powietrza stanowiącym źródło kondensacji pary wodnej, powoduje wzrost w stosunku do strefy podmiejskiej liczby dni pochmurnych. Zanieczyszczenie powietrza jest także czynnikiem zmniejszającym ilość energii słonecznej docierającej do powierzchni miasta (Diehl 1997, Wysmyk-Lamprecht i in. 2007).

Do czynników kształtujących lokalną dynamikę powietrza w Łodzi należy ukształtowanie terenu i wpływ kulminacji Wzniesień Łódzkich na ograniczoną dostawę wiatrów z kierunków północnych, a także modyfikacja naturalnych kierunków wiatrów wywołana układem zabudowy północ-południe, prostopadłej do najczęstszych - zachodnich kierunków przemieszczania się mas powietrza. Zwarta zabudowa miejska oddziałuje 
na prędkość wiatrów, większych w strefie dowietrznych części miasta. Największe korytarze wymiany mas powietrza nad Łodzią kształtują się równoleżnikowo, wzdłuż równoleżnikowych odcinków dolin rzecznych: Sokołówki, który zbacza ku północy wzdłuż zachodniej ściany Lasu Łagiewnickiego, wzdłuż doliny Łódki i Neru. Ich przebieg ulega zaburzeniu w centralnej, zurbanizowanej części miasta. Sztuczną barierę dla rozwijania prędkości wiatrów zachodnich w głównych arteriach wentylacyjnych stanowi wysoka zabudowa mieszkaniowa lokowana, wzdłuż dolin rzecznych. Główne strefy blokad swobodnego przepływu mas powietrza występują wzdłuż doliny Sokołówki, w dolinie Olechówki, pomiędzy ulicami Rzgowską i Trybunalską, w dolinie Łódki - wzdłuż ulicy Strykowskiej, w rejonie Manufaktury oraz ul. Krańcowej (Złotno), w pasie pomiędzy ulicami Piłsudskiego i Pomorską w równoleżnikowym odcinku doliny Jasienia (Bald 2009).

\subsubsection{Tereny zieleni i chronione}

W granicach administracyjnych Łodzi obszary leśne zlokalizowane są w północnej, zachodniej i w najmniejszym stopniu południowej części miasta. Wszystkie lasy na terenie miasta stanowią własność gminy oraz Skarbu Państwa (w zarządzie Nadleśnictw: Brzeziny i Grotniki).

Największy kompleks leśny o powierzchni 1200 ha, stanowi Las Łagiewnicki, zlokalizowany w północnej, granicznej części miasta. Obecnie jest także jednym z największych w Europie kompleksów leśnych znajdujących się w granicach miasta. Obejmuje lasy będące pozostałością po pradawnej Puszczy Łódzkiej. Współcześnie stanowi także wschodni fragment Parku Krajobrazowego Wzniesień Łódzkich. W środkowo-zachodniej części Lasu Łagiewnickiego znajduje się rezerwat przyrody o powierzchni 69,85 ha, którego celem jest ochrona lasu o unikalnych walorach przyrodniczych, wyróżniającego się wybitnymi zespołami roślinnymi. Należą do nich przede wszystkim zróżnicowane pod względem wilgotnościowym i troficznym zbiorowiska grądowe z dębem, grabem i domieszką brzozy, świerka i wiązu oraz z jodłą występującą tu na północnej granicy zasięgu. Teren rezerwatu porastają także dąbrowy świetliste $\mathrm{z}$ dębem bezszypułkowym, $\mathrm{z}$ bogatą florą w runie, stanowiące zanikający w Polsce typ lasu (Kurowski 1998). W północnej części miasta znajdują się także: kompleks leśny „Harcerski Las” i „Helenówek”, uroczysko „Opolska - Beskidzka” położone między ulicami: Iglastą i Beskidzką, uroczysko „Żabieniec” zlokalizowane na północnym stoku doliny „Sokołówki” oraz uroczysko „Zjazdowa”.

W zachodniej części miasta znajdują się tereny leśnie ściśle związane z doliną rzeki Łódki. Drugi co do wielkości obszar leśny „Lublinek”, położony jest w pobliżu Portu Lotniczego. W jego obrębie występują zarówno 
siedliska leśne w typie borów sosnowych oraz śródleśne podmokłe i zatorfione siedliska łąkowe, charakteryzujące się dużą różnorodnością florystyczną.

Trzeci co do wielkości obszar leśny w granicach miasta stanowi uroczysko „Ruda Popioły”. W skład drzewostanu lasu wchodzą głównie sosna i brzoza, ponadto występują tu klony, olsze, modrzewie, jawory i graby. Do najcenniejszych przyrodniczo części uroczyska należą obszary porośnięte grądami. W południowej części miasta znajduje się także najmniejsze powierzchniowo uroczysko „Przy Olechówce”.

We wschodniej części miasta znajdują się uroczysko „Przy Zakładowej”, na które składają się tryz niewielkie kompleksy leśne położone po dwóch stronach ul. Zakładowej w dzielnicy Olechów oraz uroczysko „Feliksin”, fragment większego kompleksu leśnego zlokalizowanego między ul. Wieńcową a ul. Dworcową.

Ponadto, w granicach miasta, oprócz Lasu Łagiewnickiego znajduje się rezerwat leśny „Polesie Konstantynowskie” o powierzchni 9,8 ha, położony jest przy ul. Krzemienieckiej w obrębie Parku im. J. Piłsudskiego. Przedmiotem ochrony rezerwatowej jest las naturalny z jodłą na północnej granicy zasięgu, stanowiący pozostałość pradawnej Puszczy Łódzkiej oraz pełnienie funkcji dydaktyczno-naukowej i estetycznej (Kurowski i in. 1996). „Polesie Konstantynowskie” jest najstarszym w Polsce i jednym z najstarszych w Europie rezerwatów leśnych zlokalizowanych w obrębie miast. Dawniej strefa peryferyjna miasta przekształciła się strefę silnie zurbanizowaną. Rezerwat nie jest przestrzenią publicznie dostępną a jego zwiedzanie jest dopuszczalne wyłącznie pod kierunkiem przewodnika, nauczyciela, instruktora Straży Ochrony Przyrody lub Ligi Ochrony Przyrody, mimo to teren nie jest dostatecznie zabezpieczony przed niekontrolowaną penetracją i jest niszczony. W południowej granicznej części miasta znajduje się Zespół przyrodniczo-krajobrazowy Międzyrzecze Neru i Dobrzynki (Wysmyk-Lamprecht i in. 2007).

\section{LITERATURA}

Alexandrowicz S. W., 1999, Współczesne środowisko przyrodnicze. Budowa geologiczna, [w:]: L. Starkel (red.), Geografia Polski. Środowisko przyrodnicze, PWN, Warszawa.

Bald K., 2010. Studium uwarunkowań i kierunków zagospodarowania przestrzennego miasta Łodzi. Miejska Pracownia Urbanistyczna w Łodzi, Łódź.

Czerwieniec M., Lewińska J., 2000, Zieleń w mieście, IGPiK, Kraków.

Diehl J., 1997, Założenia polityki ekologicznej miasta Łodzi. Lokalna Agenda 21, UMŁ, Wydział Ochrony Środowiska, Łódź. 
Dylik J., 1948a, O genezie pagórków okolic Chojen, Rzgowa i Rudy Pabianickiej, „Sprawozd. z Czyn. i Pos. ŁTN”, 3, 2.

Dylik J., 1948b, Ukształtowanie powierzchni i podział na krainy podłódzkiego obszaru, „Acta Geogr. Univ. Lodz.”, 1.

Dylikowa A., 1973, Geografia Polski. Krainy geograficzne, PZWS.

Fortuniak K., 2003, Miejska wyspa ciepła. Podstawy energetyczne, studia eksperymentalne, modele numeryczne i statystyczne, Wyd. UŁ, Łódź.

Goździk J., Wieczorkowska J., 2002, Rzeźba terenu. Atlas miasta Łodzi, ŁTN, Łódź.

Klatkowa H., 1965, Niecki i doliny denudacyjne w okolicach Łodzi, „Acta Geogr. Lodz.", 18.

Klatkowa H., 1972, Paleogeografia Wyżyny Łódzkiej i obszarów sq̨siednich podczas zlodowacenia warciańskiego, „Acta. Geogr. Lodz.”, 28.

Klatkowa H., Piwocki M., 1981, Objaśnienia do Mapy geologicznej Polski 1:200 000 ark. Łódź, Inst. Geol., Warszawa.

Kondracki J., 1998, Geografia regionalna Polski, Wyd. PWN, Warszawa..

Koter M., 1974, Środowisko przyrodnicze obszaru obecnej Łodzi jako podłoże rozwoju osadnictwa $w$ okresie przedprzemysłowym, Studium rozwoju osadnictwa na obszarze obecnej Łodzi w okresie przedprzemysłowym, Studia i Materiały Rady Naukowej przy Prezydencie Miasta Łodzi, z. 1.

Koter M., Liszewski S., Suliborski A., 2000, Łódź i region Polski Środkowej, ŁTN, Łódź.

Krzemiński T., 1974, Przyrodnicze podstawy rozwoju Łodzi, „Przegląd Ekonomiczno-Społeczny m. Łodzi", nr 1.

Szulczewska B., Kaftan J. (red.), 1996, Kształtowanie systemu przyrodniczego miasta, IGPiK, Kraków.

Kurowski J. K., 1998, Park Krajobrazowy Wzniesień Łódzkich. Monografia, Wojewódzki Fundusz Ochrony Środowiska i Gospodarki Wodnej w Łodzi, EkoWynik, Łódź.

Kurowski J. K., Andrzejewski H., Filipiak E., Mamiński M., 1996, Rezerwaty regionu łódzkiego, ZO LOP, Eko-Wynik, Łódź.

Lindner L., Marks L., 2012, O podziale klimatostratygraficznym kompleksu środkowopolskiego w plejstocenie Polski, „Przegląd Geologiczny”, vol. 60, nr 1.

Maksymiuk Z., Jokiel P., 1993, Mapa Hydrograficzna 1:50000, ark. Andrzejów, Geopol.

Nowacki K., 1993, Objaśnienia do Szczegółowej Mapy Geologicznej Polski 1:50 000, ark. Łyszkowice. PIG, Warszawa.

Nowacki K., Trzmiel B., 1984, Szczegółowa Mapa Geologiczna Polski 1:50 000, ark. Łódź Wschód. Wyd. Geologiczne, Warszawa.

Nowacki K., Trzmiel B., 1987, Objaśnienia do Szczegółowej Mapy Geologicznej Polski 1:50 000, Arkusz Łódź Wschód. Wyd. Geologiczne, Warszawa. 
Nowicki Z. (red.), 2007, Wody podziemne miasta wojewódzkich Polski, Informator Państwowej Służby Hydrogeologicznej, Warszawa.

Piwocki M., 1980, Mapa geologiczna Polski 1:200 000 ark. Łódź, wyd. B. PIG. Warszawa.

PN-81 B-03020, Grunty budowlane. Posadowienie bezpośrednie budowli. Obliczenia statyczne i projektowanie, PKN.

Przewoźniak M., 2002, Kształtowanie środowiska przyrodniczego miast. Przykłady z regionu gdańskiego, Wydział Architektury Politechniki Gdańskiej, Gdańsk.

Różycki F., Kulczyński S., 1962, Szczegółowa Mapa Geologiczna Polski 1:50 000, ark. Łódź Zachód. Wyd. Geologiczne, Warszawa.

Sołtys J., 2010, Struktura miasta a zasady rozwoju zrównoważonego - wybrane problemy, „Czasopismo Techniczne”, z. 14. „Architektura” z. 6-A2.

Studium uwarunkowań i kierunków zagospodarowania miasta Łodzi, uchwała $\mathrm{nr}$ XCIX/1826/10 Rady Miejskiej w Łodzi z dnia 27 października 2010 roku.

Szulczewska B., Kaliszuk W., 2005, Koncepcja systemu przyrodniczego miasta: geneza, ewolucja i znaczenie praktyczne, „Teka Kom. Arch. Urb. Stud. Krajobr. OL PAN", 7-24.

Topographische Karte, ark. Ruda Pabianitzka, 1944 r.

Turkowska K., 2006, Geomorfologia regionu łódzkiego, Wydawnictwo Uniwersytetu Łódzkiego, Łódź.

Wesołowski J., 2002, Atlas Miasta Łodzi, Plansza VI: Łódź w okresie międzywojennym i w latach okupacji hitlerowskiej, Mapa 2: Wzrost przedmieść, ŁTN, UMŁ, Łódź.

Wijnands F.G., Vereijken P., 1992, Regional-wise development of prototypes of integrated arable farming and outdoor horticulture, Netherlands J. Agric. Sci. 40: 225-238.

Wysmyk-Lamprecht B., Stobińska A., Jach K., Miłosz M., 2007, Opracowanie Ekofizjograficzne sporzq̨dzone na potrzeby Studium uwarunkowań i kierunków zagospodarowania przestrzennego miasta Łodzi, Łódź.

Z biegiem łódzkich rzek, 2010, Urząd Miasta Łodzi, Łódź.

Zajączkowski S. M., 1973, Rozwój osadnictwa na obszarze obecnej Łodzi do końca XVI wieku, Studium rozwoju osadnictwa na obszarze obecnej Łodzi w okresie przedprzemysłowym, „Studia i Materiały Rady Naukowej przy Prezydencie Miasta Łodzi", z. 2.

Ziomek J., Iwańcz T., Laskowski S., 2002, Geologia i gleby. Atlas miasta Łodzi, ŁTN, Łódź.

www.lodz.stat.gov.pl

www.emgsp.pgi.gov.pl 